\title{
ScIentilific Note
}

\section{First record of Mahanarva spectabilis (Distant) (Hemiptera: Cercopidae) in the state of Acre, Brazil}

\author{
Rodrigo Souza Santos $^{1 \bowtie \bullet}$, Carlos Mauricio Soares de Andrade ${ }^{2 \oplus}$ \& Gervásio Silva Carvalho ${ }^{3 \odot}$
}

1. Embrapa Acre, Laboratório de Entomologia, Rio Branco, AC, Brazil. 2. Embrapa Acre, Rio Branco, Brazil, AC. 3. Pontifícia Universidade Católica do Rio Grande do SUI - PUCRS, Porto Alegre, RS, Brazil.

\section{EntomoBrasilis 14: e962 (2021)}

\section{Edited by:}

Rafael Boldrini

Article History:

Received: 09.viii.2021

Accepted: 11.iv. 2021

Published: 24.x.2021

$\triangle$ Corresponding author:

name complete

ఈ rodrigo.s.santos@embrapa.br

Funding agencies:

$\checkmark$ Without funding declared

\begin{abstract}
Spittlebugs are among the main insect pests of forage grasses in Brazil. In February 2021, a spittlebug infestation was verified in Xaraés palisadegrass (Brachiaria brizantha cv. Xaraés) in the municipality of Senador Guiomard, Acre state, Brazil. The specimens were captured with an entomological sweep net and identified as Notozulia entreriana (Berg) and Mahanarva spectabilis (Distant) (Hemiptera: Cercopidae). Notozulia entreriana is frequently captured in studies with spittlebugs in Acre state, though this is the first record of $M$. spectabilis in the state. This new record expands the species known geographical distribution in Brazil and the number of species of Mahanarva occurring in Acre state.
\end{abstract}

Keywords: Amazon; Auchenorrhyncha; Forage crops; Poaceae; Sugarcane froghoppers. ivestock rearing, defined as the breeding and raising of animals for economic purposes or sustenance, is an important economic activity worldwide (Souza SoBrinHo et al. 2011). In Acre state, Brazil, beef cattle rearing is one of the main activities among small, medium, and large producers (VALENTIM 2006), representing the largest primary industry in the state in terms of economic impact (URBANSKI 2016).

Pastureland, both cultivated and natural, is the main source of feed for cattle herds, especially in Brazilian cattle operations. Cattle pastures, however, are vulnerable to insect infestations, outbreaks of which can cause severe economic impacts (TEIXEIRA \& COSTA 2016).

In Brazil, spittlebugs (Hemiptera: Cercopidae) are considered pasture pests of significant concern, causing declines in the production and quality of pasture grasses (VALÉRIO 2009; TEIXEIRA \& COSTA 2016), which can cause degradation of the pasture. The damage caused to plants is due to the feeding behavior of nymphs and adults, which reduces the nutrients available for plant growth, while toxins present in the saliva of adults enter plant tissues and cause yellowing, drying, and death in grass plants (VALÉRIO 2009). The diversity of spittlebug species increases the complexity of the problem, with individual species associated with various pasture grasses, which occur in different ecological conditions and management systems (VAlÉRIO 2009; Tolotti et al. 2018).

Currently, 25 species of cercopids have been recorded in Brazilian pasturelands, belonging to eight genera (ToLoTTI et al. 2018). Of these, eight species belong to Mahanarva: Mahanarva fimbriolata (Stål), Mahanarva vittata (Walker), Mahanarva liturata (Le Peletier and Serville), Mahanarva posticata (Stål), Mahanarva rubicunda (Walker), Mahanarva mura (China and Myers), Mahanarva tristis (Fabricius), and Mahanarva spectabilis (Distant) (ToLotrı et al. 2018). It should be noted that, although Mahanarva rubrovenata Paladini and Carvalho, Mahanarva webbi Paladini and Carvalho, and Mahanarva dabliosignata Paladini and Carvalho (Hemiptera: Cercopidae) (Paladini \& Carvalho 2007) do occur in Brazil, the pasture grasses with which they co-occur in the country have not yet been ascertained. Nonetheless, spittlebugs belonging to the genus have been reported to cause severe damage in grasses in South and Central America (Fewkes et al. 1969; VALÉRIO 2008).

In the state of Acre, six species of spittlebugs have been recorded: Deois flavopicta (Stål), Deois rubropicta Sakakibara, Deois incompleta (Walker), Notozulia entreriana (Berg), M. tristis, and M. mura (TolottI et al. 2018; SANTOS \& SUTIL 2021). The aim of this study, then, is to document the first recorded occurrence of $M$. spectabilis associated with pastureland in Acre state.

In February of 2021, a field visit was carried out in a pasture of Xaraés palisadegrass [Brachiaria brizantha (Hochst. ex A. Rich.) cv. Xaraés, Poaceae], which had been attacked by spittlebugs. The pasture was located in the Fazenda Riachuelo in the municipality of Senador Guiomard, Acre state $\left(10^{\circ} 14^{\prime} 36.3^{\prime \prime} \mathrm{S} ; 67^{\circ} 30^{\prime} 12.5^{\prime \prime} \mathrm{W}\right)$.

A collection of spittlebugs using an entomological sweep net was carried out over an area of approximately 0.5 ha. The insects were stored in a plastic bag containing diethyl ether-soaked cotton. The material was transported to the Embrapa Acre Entomological Laboratory, municipality of Rio Branco, Acre, screened under a stereoscopic microscope and preserved in a glass jar containing $70 \%$ ethanol. The insects were subsequently identified following CARVALHO \& WebB (2005).

The species $N$. entreriana and $M$. spectabilis (Figure 1) were captured in Xaraés palisadegrass, of which five males (specimen numbers: MCTP 66984 // MCTP 66985 // MCTP 66986 // MCTP 66987 // MCTP 66988) and five females 
(specimen numbers: MCTP 66989 // MCTP 66990 // MCTP 66991 // MCTP 66992 // MCTP 66993) belonged to M. spectabilis. The specimens were deposited in the collection of the Museum of Science and Technology of the Pontifícia Universidade Católica do Rio Grande do Sul, municipality of Porto Alegre, Rio Grande do Sul state, Brazil.

Meanwhile, $N$. entreriana is commonly found in cercopid studies carried out in Acre state (FAzolin et al. 2009; 2012; SUTIL et al. 2020; SANTOS \& SUTIL 2021). Its presence in the Amazon has also been recorded in the states of Rondônia and Pará (TolotTl et al. 2018). Currently, it has been associated with host plants belonging to the following genera: Axonopus, Brachiaria, Cenchrus, Chloris, Chrysopogon, Cynodon, Digitaria, Eriochloa, Hemarthria, Hyparrhenia, Melinis, Panicum, Paspalum, Pennisetum, Rhynchospora, Setaria, Tripsacum, and Zoysia (TolotTl et al. 2018).

In Brazil, M. spectabilis, locally known as cigarrinha-vermelhada-cana (literally, "red cane spittlebug"), has already been recorded on the following grass species: $B$. brizantha, Brachiaria decumbens Stapf, and Pennisetum purpureum Schum (Auad \& Carvalho 2009; Tolloti et al. 2018), as well as on sugarcane (Saccharum officinarum L., Poaceae) (Alves \& CARVAlHo 2014).

The species measures around $12 \mathrm{~mm}$ in length, is generally reddish-brown to ochre, with a reddish-brown or ochre pronotum and scutellum, tegmina ochre yellow with black lengthwise stripes, though different wing patterns can occur, with colors ranging from reddish to black tegmina (ToLoTTI et al. 2018) (Figure 1). Records of M. spectabilis exist from the Federal District and the states of Goiás, Mato Grosso,
Maranhão, Mato Grosso do Sul, Minas Gerais, Pará, Paraná, Rondônia, São Paulo, and Tocantins (Tolotrı et al. 2018). The species has been identified as a pest that limits the production of forage grasses in Brazil (AUAD et al. 2007).

According to RESENDE et al. (2013), the presence of eight adults of M. spectabilis over six days in clumps of Brachiaria ruziziensis Germain and Everard with an average of 80 tillers is enough to cause drops in chlorophyll and reduce plant function by up to $60 \%$, confirming the insect's significant adverse potential in pasturelands.

In addition to $M$. spectabilis, two other congeneric species occur in Acre state, namely M. tristis, recorded in sugarcane, and B. brizantha (FAzolin et al. 2009) and M. mura, also in Xaraés palisadegrass (TolotTI et al. 2018; SUTIL et al. 2020; SANTOS \& SUTIL 2021).

When the field visit was carried out, visual observation and the number of specimens captured allowed confirmation of the fact that the population of $M$. spectabilis was greater than $N$. entreriana in the infested area. In addition, it was observed that the infestation was spread throughout the farm's pastureland and the damage to grass tussocks was easily visible. Xaraés palisadegrass is currently the most widely planted forage grass in Acre, mostly due to its resistance to brizantha grass death syndrome (ANDRADE \& Assis 2008). Therefore, there is an urgent need to develop a monitoring plan and chemical or biological control strategies against $M$. spectabilis, given the susceptibility of Xaraés palisadegrass to the species.

This record from the municipality of Senador Guiomard aids

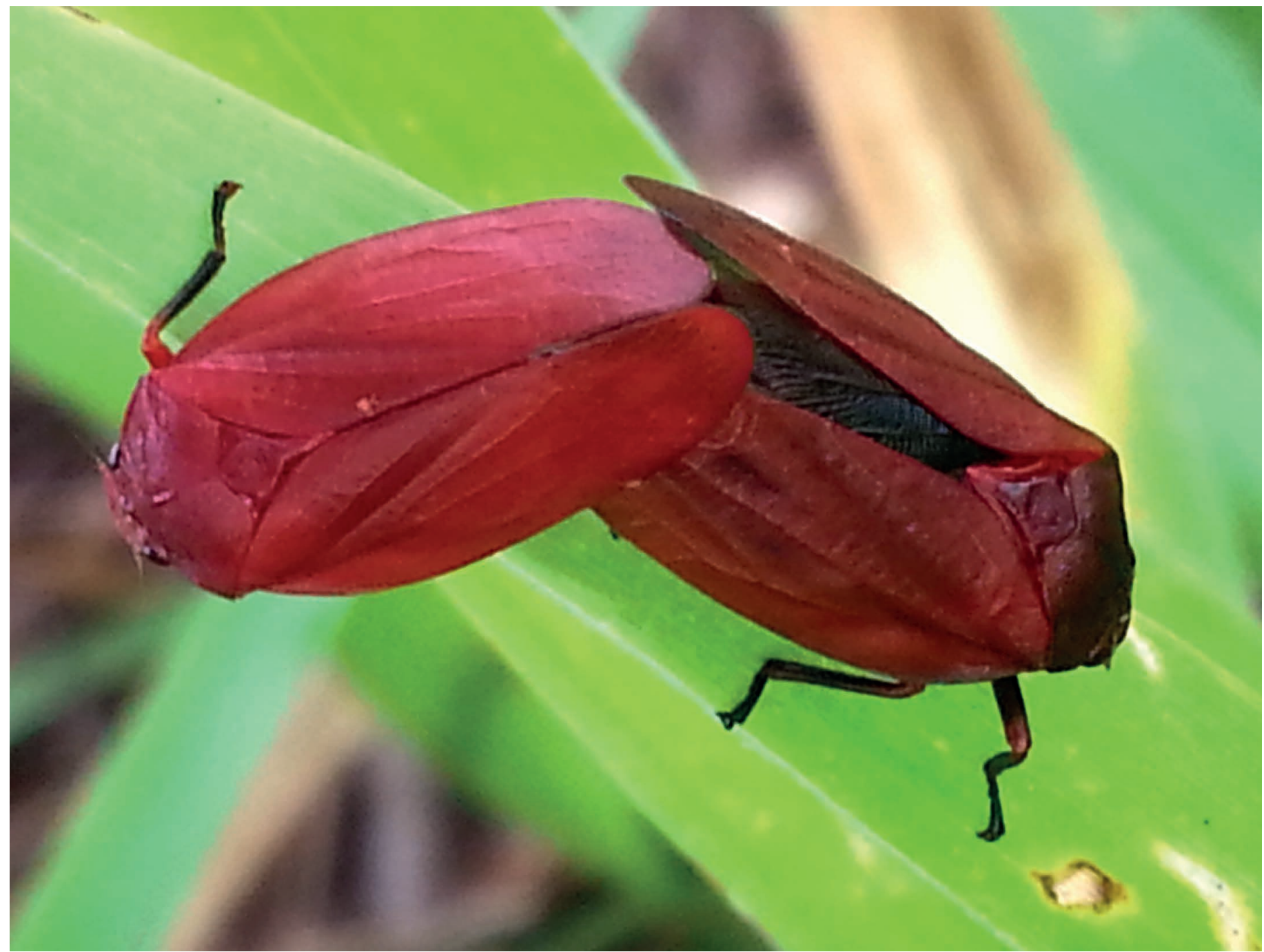

Figure 1. Adults of Mahanarva spectabilis (Hemiptera: Cercopidae) in copula. (Photo: Gervásio Silva Carvalho). 
in the understanding of cercopid species present in Acre state, as well as the geographical distribution of M. spectabilis in Brazil. Furthermore, it confirms the first record of the species in this state.

\section{REFERENCES}

Andrade, CMS \& GML de Assis, 2008. Capim Xaraés: cultivar de gramínea forrageira recomendada para pastagens no Acre. Rio Branco: Embrapa Acre (Documentos, 112).

Alves, RT \& GS Carvalho, 2014. Primeiro registro das espécies de cigarrinhas-da-raiz da cana-de-açúcar Mahanarva spectabilis (Distant) e Mahanarva liturata (Le Peletier \& Serville) atacando canaviais na região de Goianésia, GO, Brasil. Arquivos do Instituto Biológico, 81: 83-85. DOI: https://doi.org/10.1590/S1808-16572014000100016

Auad, AM \& CA de Carvalho, 2009. Desenvolvimento e viabilidade de ovos de Mahanarva spectabilis (Distant, 1909) (Hemiptera: Cercopidae) submetidos a diferentes regimes de hidratação. Arquivos do Instituto Biológico, 76: 911-914. DOI: https://doi.org/10.1590/1808$1657 v 76 p 7112009$

Auad, AM, AD Simões, AV Pereira, ALF Braga, SS F, FJS Lédo, SV Paula-Moraes, SA Oliveira \& RB Ferreira, 2007. Seleção de genótipos de capim-elefante quanto à resistência à cigarrinha-das-pastagens. Pesquisa Agropecuária Brasileira, 42: 1077-1081. DOI: https://doi.org/10.1590/ S0100-204X2007000800003

Carvalho, GS \& MD Webb, 2005. Cercopid spittlebugs of the New World (Hemiptera, Auchenorrhyncha, Cercopidae). Pensoft, Sofia.

Fazolin, M, MJ Thomazini \& JLV Estrela, 2012. Pragas das culturas de importância econômica para o Estado do Acre. Rio Branco: Embrapa Acre (Documentos, 127).

Fazolin, M, CR da Costa, JLV Estrela, CE Hessel \& CMS de Andrade, 2009. Levantamento de insetos associados aos capins tanner-grass, tangola e estrela-africana no Acre. Amazônia: Ciência e Desenvolvimento, 4: 161-173.

Fewkes, DW, 1969. The biology of sugar cane froghopper. pp. 281-307. In: Williams, JR, JR Metcalfe, RW Mungomery \& R Mathes (Eds.). Pests of sugar cane. Amsterdam: Elsevier Publishing.

Paladini, A \& GS Carvalho, 2007. Descrição de três novas espécies de Mahanarva (Hemiptera, Cercopidae, Ischnorhininae). Iheringia, Série Zoologia, 97: 57-66. DOI:
https://doi.org/10.1590/S0073-47212007000100009

Resende, TT, AM Auad, MG Fonseca, Souza Sobrinho F, DR dos Santos \& SEB da Silva, 2013. The damage capacity of Mahanarva spectabilis (Distant, 1909) (Hemiptera: Cercopidae) adults on Brachiaria ruziziensis pastures. The Scientific World Journal, 4: 281295. DOI: https://doi.org/10.1155/2013/281295

Santos, RS, WP Sutil, 2021. Levantamento de cigarrinhasdas-pastagens (Hemiptera: Cercopidae) no município de Senador Guiomard, Acre, Brasil. Entomology Beginners, 2: e015. DOI: https://doi.org/10.12741/2675-9276.v2.e015

Souza Sobrinho, F, FJS Lédo \& MM Kopp, 2011. Estacionalidade e estabilidade de produção de forragem de progênies de Brachiaria ruziziensis. Ciência e Agrotecnologia, 35: 684-691. DOI: https://doi.org/10.1590/S141370542011000400006

Sutil, WP, RS Santos \& LC de Oliveira, 2020. Controle químico de cigarrinhas-das-pastagens no estado do Acre, pp. 101106. In: Álvares, V de S \& FM Estanislau (Eds.). Seminário da Embrapa Acre de Iniciação Científica e Pós-Graduação, 2. A contribuição da ciência para a agropecuária no Acre. Anais... Rio Branco, AC: Embrapa Acre.

Teixeira, CAD \& JNM Costa, 2016. Pastagens, pp. 392-417. In: Silva, NM da, R Adaime \& RA Zucchi (Eds.). Pragas agrícolas e florestais na Amazônia. Brasília: Embrapa.

Tolotti, A, WS de Azevedo-Filho, VH Valiati, GS Carvalho \& JR Valério, 2018. Cigarrinhas-das-pastagens em gramíneas forrageiras no Brasil. Porto Alegre, Evangraf.

Urbanski, AS, 2016. Consórcio de pastagens como ferramenta para aumento de produtividade animal na Amazônia Ocidental. 2016. 45f. Dissertação (Mestrado em Sanidade e Produção Animal Sustentável na Amazônia). Universidade Federal do Acre.

Valentim, JF, 2006. Produção e potencial para a agropecuária no Acre. Rio Branco: Secretaria do Meio Ambiente - SEMA/ Programa Estadual de Zoneamento Econômico-Ecológico do Estado do Acre - Fase II (Documento).

Valério, JR, 2009. Cigarrinhas-das-pastagens. Campo Grande: Embrapa Gado de Corte (Documentos, 179).

Valério, JR, 2008. Cigarrinhas-das-pastagens: bioecologia, importância e alternativas de controle. pp. 353-372. In: Pereira, OG (Ed.). Simpósio sobre manejo estratégico da pastagem, 4.; Simpósio internacional sobre produção animal em pastejo, 2. Anais...Viçosa: UFV/DZO.

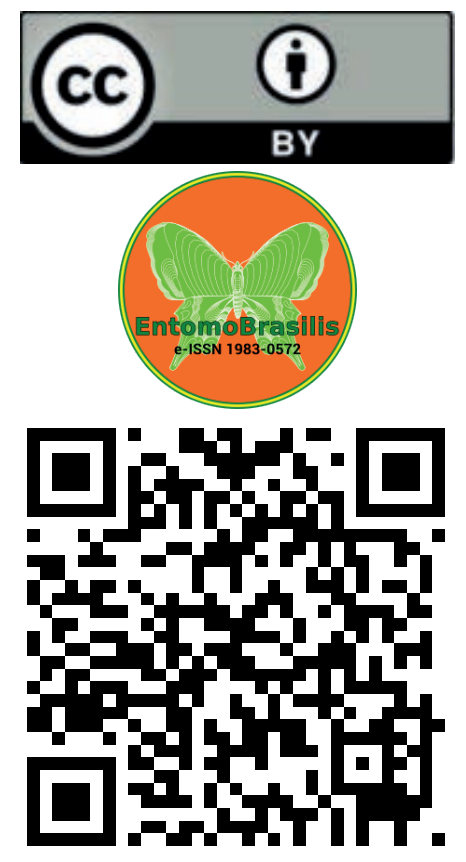

